\title{
Correction to: Gold standard for nutrition: a review of human milk oligosaccharide and its effects on infant gut microbiota
}

\author{
Shunhao Zhang ${ }^{1 \dagger}$, Tianle $\mathrm{Li}^{1 \dagger}$, Jing Xie ${ }^{1}$, Demao Zhang ${ }^{1}$, Caixia $\mathrm{Pi}^{1}$, Lingyun Zhou ${ }^{2^{*}}$ and Wenbin Yang ${ }^{3^{*}}$
}

\section{Correction to: Microb Cell Fact (2021) 20:108} https://doi.org/10.1186/s12934-021-01599-y

Following publication of the original article [1], the authors identified a problem with the authorship. In the original authorship, Tianle Li had been erroneously detailed as the second author. However, as Shunhao Zhang and Tianle Li contributed equally to this work, Tianle Li should in fact be regarded as a co-first author.

The authorship has been updated in the original article and the correct authorship may be seen in this correction.

The authors apologize for this mistake and any inconvenience caused. All authors agree to this correction of authorship.

\section{Author details}

${ }^{1}$ State Key Laboratory of Oral Disease, National Clinical Research Center for Oral Disease, West China Hospital of Stomatology, Sichuan University, Chengdu 610041, Sichuan, China. ${ }^{2}$ Center of Infectious Diseases, West China Hospital of Sichuan University, No. 37 Guoxue Alley, Wuhou District, Chengdu 610041, China. ${ }^{3}$ State Key Laboratory of Oral Diseases, National
Clinical Research Center for Oral Diseases, Department of Oral and Maxillofacial Surgery, Department of Medical Affairs, West China Hospital of Stomatology, Sichuan University, No. 14, Section 3, South Renmin Road, Chengdu 610041, Sichuan, China.

Published online: 21 July 2021

\section{Reference}

1. Zhang S, LiT, Xie J, Zhang D, Pi C, Zhou L, Yang W. Gold standard for nutrition: a review of human milk oligosaccharide and its effects on infant gut microbiota. Microb Cell Fact. 2021;20(1):108. https://doi.org/10.1186/ s12934-021-01599-y.

\section{Publisher's Note}

Springer Nature remains neutral with regard to jurisdictional claims in published maps and institutional affiliations.

The original article can be found online at https://doi.org/10.1186/s12934021-01599-y.

\footnotetext{
*Correspondence: lingyunzhou@scu.edu.cn; yangwenbin@scu.edu.cn

${ }^{\dagger}$ Shunhao Zhang and Tianle Li contributed equally to this work

${ }^{2}$ Center of Infectious Diseases, West China Hospital of Sichuan University,

No. 37 Guoxue Alley, Wuhou District, Chengdu 610041, China

${ }^{3}$ State Key Laboratory of Oral Diseases, National Clinical Research

Center for Oral Diseases, Department of Oral and Maxillofacial Surgery,

Department of Medical Affairs, West China Hospital of Stomatology,

Sichuan University, No. 14, Section 3, South Renmin Road,

Chengdu 610041, Sichuan, China

Full list of author information is available at the end of the article
}

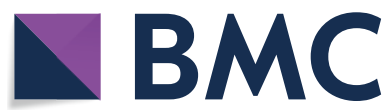

(c) The Author(s) 2021. This article is licensed under a Creative Commons Attribution 4.0 International License, which permits use, sharing, adaptation, distribution and reproduction in any medium or format, as long as you give appropriate credit to the original author(s) and the source, provide a link to the Creative Commons licence, and indicate if changes were made The images or other third party material in this article are included in the article's Creative Commons licence, unless indicated otherwise in a credit line to the material. If material is not included in the article's Creative Commons licence and your intended use is not permitted by statutory regulation or exceeds the permitted use, you will need to obtain permission directly from the copyright holder. To view a copy of this licence, visit http://creativeco mmons.org/licenses/by/4.0/. The Creative Commons Public Domain Dedication waiver (http///creativecommons.org/publicdomain/ zero/1.0/) applies to the data made available in this article, unless otherwise stated in a credit line to the data. 